\title{
Right Ventricular Cardiac Power Output as a Mortality Predictor in Patients with Pulmonary Arterial Hypertension
}

\author{
Pulmoner Arteryel Hipertansiyonda Sağ Ventrikül Kardiyak Atım Gücünün \\ Mortalite Belirteci Olarak Değerlendirilmesi
Sert Sena, Dinç Asarcıklı Lale, Zencirci Esen Aycan, Ösken Altuğ, Simsek Barıs, Yağmur Aysel, Gungor Barıs, Yildirimturk Ozlem

Department of Cardiology, Dr. Siyami Ersek Thoracic and Cardiovascular Surgery Training and Research Hospital, Istanbul, Turkey

\author{
Yazı̧sma Adresi / Correspondence: \\ Sena Sert \\ Department of Cardiology, Dr. Siyami Ersek Thoracic and Cardiovascular Surgery Training and Research Hospital 13 Tibbiye Cad., Selimiye, 34668, Uskudar, Istanbul, Turkey \\ T: +90532 $3508450 \quad$ E-mail : senasert@live.com \\ Geliş Tarihi / Received : 14.04.2021 Kabul Tarihi/Accepte: 03.11.2021
}

Orcid :

Sena Sert https://orcid.org/0000-0002-3735-1053 Lale Dinç Asarcıklı https://orcid.org/0000-0002-7828-9487 Aycan Esen Zencirci https://orcid.org/0000-0003-4235-351X Altuğ Ösken https://orcid.org/0000-0003-3018-339X
Barıș Şimşek https://orcid.org/0000-0001-9412-0035 Aysel Yağmur https://orcid.org/0000-0002-1773-1956 Barıș Güngör https://orcid.org/0000-0002-1445-1876 Ozlem Yidirimturk https://orcid.org/0000-0001-9841-4524

( Sakarya Tip Dergisi / Sakarya Med J 2021, 11(4):794-802) DOI: 10.31832/smj.915463

\footnotetext{
Abstract

Objective Right heart catheterization (RHC) is a gold standard method for diagnosis, also monitors the level of the disease, the prognosis, and the response to the therapy in patients with pulmonary arterial hypertension (PAH). Cardiac power output (CPO) is the product of flow and pressure. Aim of this study was to evaluate right ventricular cardiac power output (RVCPO) in PAH patients as a prognostic factor.

Materials Demographic characteristics, functional class, RHC findings, echocardiographic data, PAH-specific medical treatment usage of 105 treatment-naïve, newly diagnosed and Methods Group 1 PAH patients between September 2009 and June 2019 were reviewed. RVCPO (Watt) was calculated as a product of cardiac output (CO) and mean pulmonary artery pressure (mPAP), divided by a constant of 451 .

Results RVCPO was lower in high-risk patients $(0,25 \pm 0,02 \mathrm{~W}$ for high risk, $0,42 \pm 0,15 \mathrm{~W}$ for low risk, and $0,44 \pm 0,10 \mathrm{~W}$ for intermediate-risk; $\mathrm{p}=0.04)$ in comparison with low and intermediate-risk patients. RVCPO showed very high correlation with mPAP while a low positive correlation with CO, and PVR. 0,44 W for RVCPO was found the most accurate predictor value for mortality in low and intermediate-risk patients by ROC analysis.

Conclusion RVCPO could be a promising hemodynamic parameter that represents cardiac pumping ability with PAH patients. RVCPO tends to increase with low and intermediate risk while decrease with high-risk and associated with mortality above $0,44 \mathrm{~W}$ with low and intermediate-risk patients. We suggest that RVCPO could be a beneficial hemodynamic tool to discriminate the patients at-risk among the low and intermediate-risk groups.

Keywords pulmonary arterial hypertension; cardiac power output; pulmonary circulation; right heart catheterization; right ventricle hemodynamics

$\ddot{\mathrm{O} z}$

Amaç Să̆ kalp kateterizasyonu pulmoner arteryel hipertansiyonun (PAH) tanısında altın standart olmanın yanı sıra, hastalığın ciddiyetinin belirlenmesi ve takip eden süreçte tedaviye yanıtın değerlendirilmesi açısından önemli bir rol oynamaktadır. Kardiyak atım gücü (KAG) ise akım ve basıncın bir bileșkesi olup kalbin pompa fonksiyonuna ilişkin bilgi vermektedir. Çalıșmanın amacı KAG değerinin PAH hastalarında prognostik faktör olarak kullanımının araștırlmasıdır.

Gereç ve Calısmada; Eylül 2009- Haziran 2019 yılları arasında, 105 tedavi naif, yeni tanı Grup 1 PAH hastası araștırılmıștr. Araștırılan KAG değeri Watt cinsinden kardiyak atım hacmi ve ortalama Yöntemle $\quad$ pulmoner arter basıncının çarpımının 451 sabitine bölünmesi ile bulunmuștur.

Bulgular KAG değeri yüksek riskli hastalarda ( $0.25 \pm 0.02 \mathrm{~W}$ Yüksek risk, $0.42 \pm 0.15 \mathrm{~W}$ düşük risk, ve $0.44 \pm 0.10 \mathrm{~W}$ orta-risk; $p=0.04)$ düşük ve orta-riskli hastalara klyasla anlaml ölçüde düşük bulunmuștur. Orta ve düşük riskli grupta, lojistik regresyon analizi neticesinde sağ ventriküle ait KAG değeri artış gösterdikçe mortalitenin arttığı gösterilmiştir (HR: 2,06, 95\% CI: 1.1-3.03, p=0.03). Kirlma noktasinın ROC analizi ile 0.44 W olduğu,bu değerin üstündeki düşük-orta risk profilinde mortalitenin yüksek seyrettiği görülmüștür.

Sonuç KAG; kardiyak rezervi göstermesi açısından PAH hastalarında gelecek vaad eden bir parametre olarak göze çarpmaktadır. Yüksek riskli grupta rezervin tükendǐ̌̆ine işaret eder nitelikte düşük seyrederken, rezervini tam anlamıyla yitirmemiş orta-düşük riskli grupta kompansatuar rezervin üst stmırına gelecek şekilde artı̧̧ gösterdiği bu stnır aşıldıktan sonra mortalite artışının işareti olan bir parametre olarak değerlendirilebilir. 


\section{INTRODUCTION}

Clinical experience with right heart catheterization (RHC) revealed that it has the diagnostic and prognostic significance for understanding the hemodynamic process of pulmonary vascular disorders. ${ }^{1-3}$ Besides, to be a gold standard for diagnosis, RHC provides useful data to better understand the level of the disease and the prognosis, also monitors the response to the therapy. RHC also plays a role in the diagnosis and management of heart failure, shock, congenital heart disease, and valvular heart disease. Cardiac power output (CPO) is the product of flow and pressure. It represents the rate of external work done by the dedicated ventricle or the function of the heart as a mechanical pump. ${ }^{4}$ Left ventricular cardiac power output (LVCPO), was well-established as a strong independent predictor of in-hospital mortality in patients with cardiogenic shock and as a significant predictor of outcome in chronic heart failure. ${ }^{5,6}$ However, CPO for right ventricle $(\mathrm{RV})$ in pulmonary arterial hypertension (PAH) patients has not been comprehensively investigated for mortality and morbidity prediction yet. Therefore, we conducted a retrospective data analysis of the right ventricular cardiac power output (RVCPO) and assessed it based on invasive methods as a promising parameter for mortality prediction in $\mathrm{PAH}$ patients.

\section{MATERIALS and METHODS}

We reviewed medical records of 105 treatment naive, newly diagnosed Group 1 PAH patients between September 2009 and June 2019. The study designed as retrospective, observational and methodological. Baseline characteristics, RHC findings, echocardiographic data, PAH-specific medical treatment usage were recorded. Eisenmenger's Syndrome patients (n:38) were excluded from the study cause of the confounding nature of different cardiac output (CO) values of RV and left ventricle (LV) and, different mechanical dynamics of shunt amount and location.

We performed right and left-sided cardiac catheterization for each patient at baseline to assess the hemody- namic measurements. The catheterization was performed through cannulation of the femoral vein and artery under fluoroscopic guidance. Hemodynamic variables measured by RHC include CO using Fick's equation, mixed venous oxygen saturation (SvO2), pulmonary arterial pressures (PAP), pulmonary arterial wedge pressure (PAWP), right atrial pressure (RAP), and right ventricular pressure (RVP). Transpulmonary pressure gradient (TPG), pulmonary vascular resistance (PVR), and cardiac index (CI) were calculated according to predefined formulas. Hemodynamic equations were as follows; RVCPO (W) was calculated as a product of $\mathrm{CO}$ and mean pulmonary artery pressure (mPAP), divided by a constant of 451. Pulmonary vascular resistance (PVR) (Wood Units) was determined by the following equation: (mPAP - PCWP) / CO. TPG defined by the difference between MPAP and PCWP. Patients were diagnosed as PAH if they had a mean pulmonary arterial pressure (mPAP) of $\geq 25 \mathrm{mmHg}$, a wedge pressure of $\leq 15 \mathrm{mmHg}$, and PVR $\geq 3 \mathrm{WU}$ in RHC. 7 Transthoracic echocardiography data were recorded as well. 6-minute walk distance (6MWD), World Health Organization (WHO) functional class, and N-terminal Pro-brain natriuretic peptide (NT-Pro-BNP) values were also considered for risk stratification. We used the European Society of Cardiology/European Respiratory Society (ESC/ERS) guidelines risk assessment tool for stratification.7

The participants of this study provided written informed consent of the utilization of their medical records. All subjects gave informed consent, the study complied with the Declaration of Helsinki, and the trial was approved by the institutional local ethics committee (The protocol code: 27.07.2020 Versiyon 1- HNEAH-KAEK 2020/KK7158.). No external support has received.

\section{Statistical analysis}

The variables were investigated using visual (histograms, probability plots) and analytical methods (Kolmogorov-Smirnov/Shapiro-Wilk's test) to determine whether they are normally distributed. Descriptive analyses were 
presented using mean \pm standard deviations for normally distributed and medians and interquartile ranges (IQR) for the non-normally distributed variables. Categorical variables were compared by $\mathrm{X} 2$ test. Continuous variables were compared using an independent sample Student's t-test. One-way ANOVA was used to compare RVCPO among the $\mathrm{PAH}$ subgroups and risk stratification. An overall p-value of less than 0.05 was considered to show a statistically significant result. When the overall significance was observed, pairwise posthoc tests were performed using Tukey's test. Univariate logistic regression analyses were used to identify predictors of outcome. We included the variables into the multivariate regression analysis that has already been investigated before as an indicator for the outcome in previous studies and found statistically significant in the univariate analyses separately. The variables affecting RVCPO were investigated using Spearman/Pearson correlation. Time independent association between RVCPO variable and outcome was assessed using receiver-operating characteristic curve analysis. When a significant cut-off value was observed, the sensitivity, specificity, positive and negative predictive values were presented. A p-value $<0,05$ was considered significant for all the data examined (SPSS software, version 22.0).

\section{RESULTS}

Medical records (between 2009 and 2019) of 67 PAH patients have been evaluated. Distribution of all patients among Group 1 PAH patients without Eisenmenger's Syndrome, has demonstrated as followed; 43,3\% (n:29) idiopathic pulmonary arterial hypertension (IPAH); 1,5\% (n:1) drugs and toxins induced PAH; 47,8\% (n:32) connective tissue disease associated with PAH (CTD-APAH); 7,5\% (n:5) PAH after the correction of the congenital defect without any residual shunt. All patients received targeted PAH therapy included endothelin receptor antagonists in $56(83,5 \%)$, phosphodiesterase type-5 inhibitors in $52(77,6 \%)$ and prostacyclin analogs in $35(52,2 \%)$ patients. A total of $50(74,6 \%)$ and $10(10,4 \%)$ patients received double combination of $\mathrm{PAH}$ therapies and triple combination included with an intravenous prostacyclin analogue, respectively. Baseline demographics, RHC, and echocardiographic data have shown in Table 1.

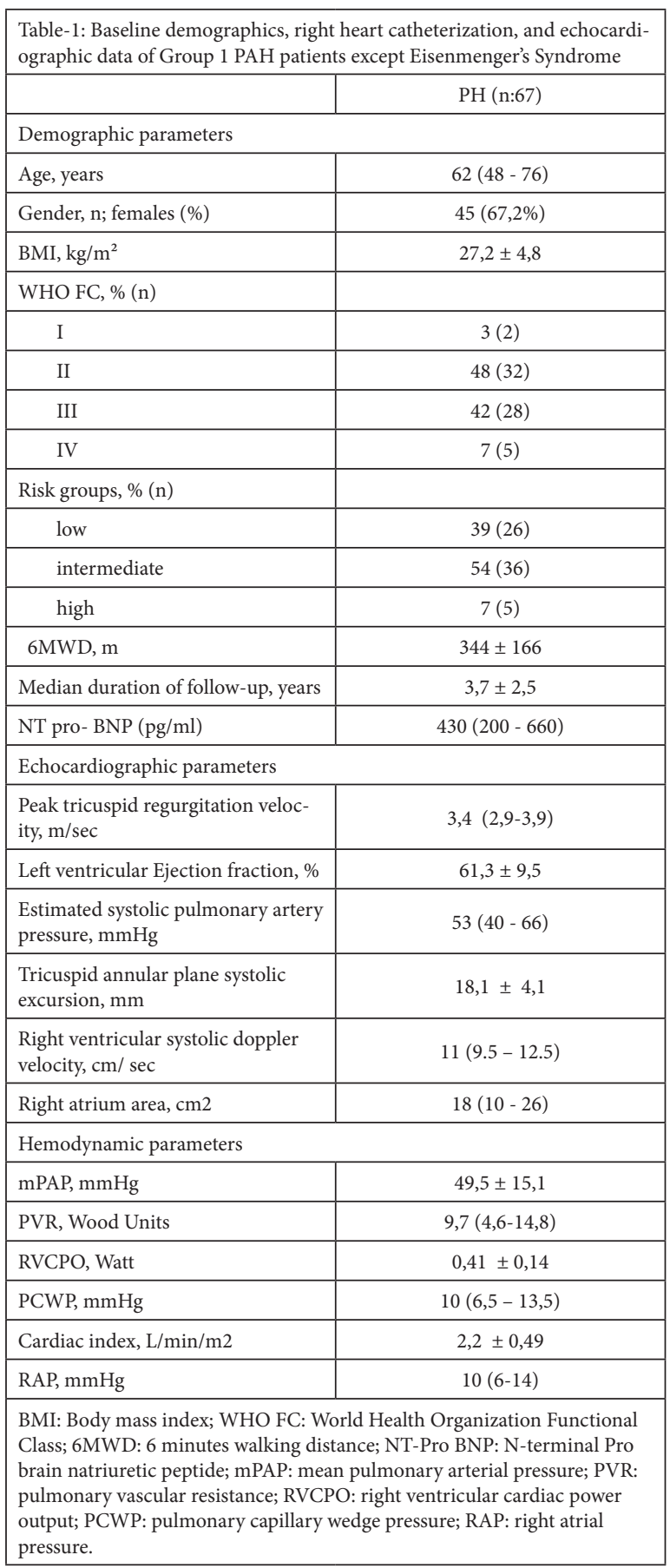




\section{Hemodynamics in relation to baseline characteristics}

The total observation period was $3,7 \pm 2,5$ years. Overall mortality was 22,4\% (n:8 with(in) IPAH, n:6 with(in) CTD-APAH, n:1 in drugs and toxins induced patients). RVCPO was increased to $0,41 \pm 0,14 \mathrm{~W}$. Female patients had a significantly lower RVCPO than men (male patients) $(0,37 \pm 0,12 \mathrm{~W}$ for women vs. $0,53 \pm 0,13 \mathrm{~W}$ for men, $\mathrm{p}$ $=0,005)$. RVCPO was found higher among obese $(\mathrm{BMI} \geq$ $30 \mathrm{~kg} / \mathrm{m} 2)$ than non-obese patients $(0,41 \pm 0.13$ vs. 0,47 $\pm 0,15, \mathrm{p}=0,100$ ) however the difference was found as non-significant. One-way ANOVA revealed that RCVPO was lower in high-risk patients $(0,25 \pm 0,02 \mathrm{~W}$ for high risk, $0,42 \pm 0,15 \mathrm{~W}$ for low risk, and $0,44 \pm 0,10 \mathrm{~W}$ for intermediate-risk; $\mathrm{p}=0,04)$ in comparison with low and intermediate-risk patients. The statistical significance was found related to the difference between high-risk to low and intermediate risk groups (Figure-1).

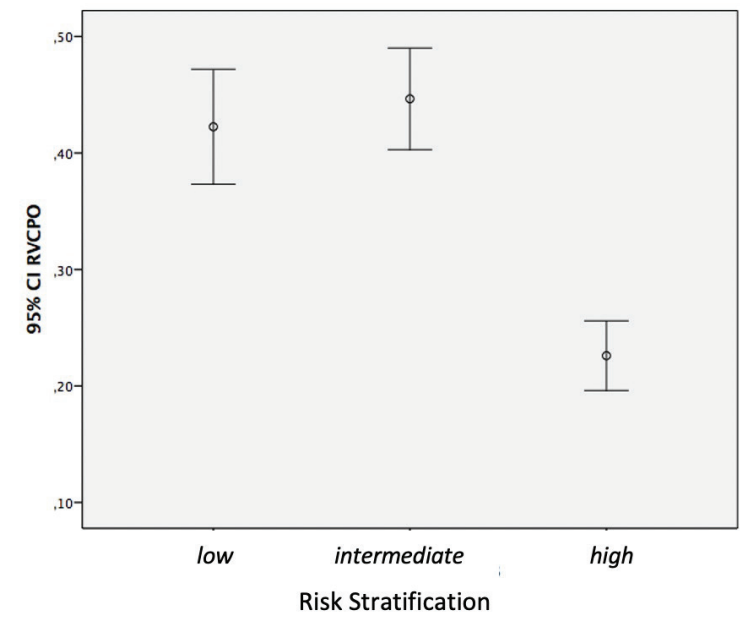

RVCPO: right ventricular cardiac power output.

Figure 1-Post-hoc analyses of RVCPO values according to risk stratification

RVCPO was not significantly different between low and intermediate-risk groups. Also, as components of RVCPO; mPAP (35 $\pm 12 \mathrm{mmHg}$ for high risk, $52 \pm 0,15 \mathrm{~W}$ for low risk and $56 \pm 6 \mathrm{mmHg}$ for intermediate-risk; $\mathrm{p}=0,003$ ) and $\mathrm{CO}(2,5 \pm 0,3 \mathrm{~L} / \mathrm{min}$ for high risk, 3,65 $\pm 0,15 \mathrm{~L} / \mathrm{min}$ for low risk and $3,55 \pm 0,11 \mathrm{~L} / \mathrm{min}$ for intermediate-risk; $\mathrm{p}=0,016)$ was higher in low and intermediate-risk patients in comparison with the high-risk population (Figure-2).

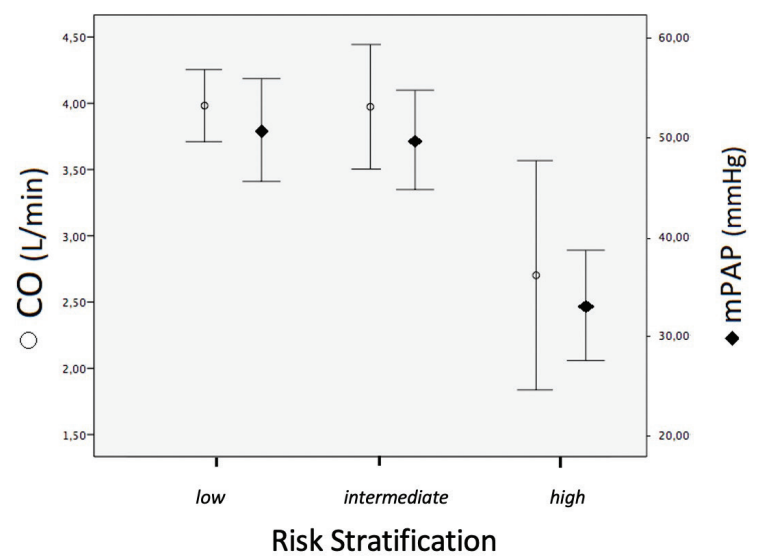

mPAP: mean pulmonary artery pressure; CO: cardiac output.

Figure 2-Post-hoc analyses of MPAP and CO values according to risk stratification

Univariate logistic regression analysis applied to low and intermediate-risk patients. The results revealed a significant relationship between mortality and RVCPO, PVR, RAP, CI, NT pro- BNP levels, 6MWD, age while mPAP, RA area, right ventricular systolic Doppler velocity (RVS), tricuspid annular plane systolic excursion (TAPSE) have shown no statistically significant relation with mortality (Table 2). For multivariate analysis, the possible factors identified with univariate analyses were further entered into the logistic regression analysis to determine independent predictors of outcome. In multivariate analysis, PVR and RVCPO (OR: 2,06, 95\% CI: 1,1-3,03, p=0,030) remained significant with the mortality among low and intermediate-risk patients (Table 3).

\section{Variables associated with RVCPO}

We examined the relationship between RVCPO and other hemodynamic variables (Table 4). The Spearman correlation test showed a significant positive (very high) correlation between the RVCPO and mPAP. TAPSE and RVS showed a low negative correlation while CO, PVR showed 
low positive and TPG have a moderate positive correlation.

Table 2. Univariate Logistic Regression results of hemodynamic, demo-
graphic, and echocardiographic variables for mortality in Group $1 \mathrm{PAH}$ patients

Variables

\begin{tabular}{|l|c|l|} 
Variables & $\begin{array}{c}\text { Odds Ratio (95\% } \\
\mathrm{CI})\end{array}$ & P value \\
\hline Demographics & & \\
\hline Age (years) & $1,063(1,021-1,106)$ & $0,003^{*}$ \\
\hline
\end{tabular}

Age (years)

NT Pro-BNP

6 Minute Walking Distance

Hemodynamic variables

m PAP, $\mathrm{mmHg}$

Right atrial pressure, $\mathrm{mmHg}$

Right Ventricular Cardiac Power Output

Cardiac index

Pulmonary Vascular Resistance

Echocardiographic variables

Right atrial area

RVS

TAPSE

(20)

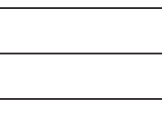

\section{p}

NT-Pro BNP: N-terminal Pro brain natriuretic peptide; mPAP: mean

TAPSE: tricuspid annular plane systolic excursion; Confidence interval:CI

Table 3. Multivariate Logistic Regression for mortality in Group $1 \mathrm{PAH}$ patients

\begin{tabular}{|l|c|c|}
\hline Variables & $\begin{array}{c}\text { Odds Ratio (95\% } \\
\text { CI) }\end{array}$ & P value \\
\hline Right Ventricular Cardiac Power Output & $2.06(1,1-3,03)$ & $0,030^{*}$ \\
\hline Pulmonary Vascular Resistance & $1,6(1,2-1,8)$ & $0,020^{*}$ \\
\hline Confidence interval:CI & \\
\hline
\end{tabular}

Table-4: The relation between RVCPO and hemodynamic and echocardiographic parameters

\begin{tabular}{|l|c|c|}
\hline Variable & $\begin{array}{c}\text { Correlation coeffi- } \\
\text { cient }(\mathrm{r})\end{array}$ & p value \\
\hline mPAP & 0,935 & $<0,001$ \\
\hline TPG & 0,511 & $<0,001$ \\
\hline Cardiac output & 0,465 & $<0,001$ \\
\hline Cardiac index & 0,333 & 0,006 \\
\hline PVR & 0,343 & 0,005 \\
\hline RVS & $-0,480$ & $<0,001$ \\
\hline TAPSE & $-0,405$ & $<0,001$ \\
\hline RVCPO: & &
\end{tabular}

RVCPO: right ventricular cardiac power output; mPAP: mean pulmonary artery pressure; TPG: transpulmonary gradient; PVR: pulmonary vascular resistance; RVS: right ventricular systolic Doppler velocity; TAPSE: tricuspid annular plane systolic excursion

\section{The cut-off value for RVCPO to determine mortality for PAH patients}

We evaluated RVCPO to determine a cut-off value as an independent hemodynamic correlate of the outcome by receiver operator characteristic (ROC) analysis, a RVCPO of $0,44 \mathrm{~W}$ was found the most accurate predictor value for mortality for low and intermediate-risk PAH patients (Figure-3). The sensitivity was calculated as $87,7 \%$ while specificity was $69,2 \%$. Positive and negative predictive values were reported in $48,4 \%, 69,2 \%$, respectively (Table-5).

Table-5: Sensitivity, specificity, positive and negative predictive values for RVCPO cut-off prediction by ROC curve analysis in the low and intermediate-risk patient population

\begin{tabular}{|l|c|c|c|c|}
\hline Cut-off & $\begin{array}{c}\text { Sensitivity } \\
(\%)\end{array}$ & $\begin{array}{c}\text { Specificity } \\
(\%)\end{array}$ & $\begin{array}{c}\text { Positive } \\
\text { predictive } \\
\text { value (\%) }\end{array}$ & $\begin{array}{c}\text { Negative } \\
\text { predictive } \\
\text { value (\%) }\end{array}$ \\
\hline $0,44 \mathrm{~W}$ & 86,7 & 69,2 & 48,4 & 69,2 \\
\hline $\begin{array}{l}\text { RVCPO: right ventricular cardiac power output; ROC: Receiver operator } \\
\text { characteristic }\end{array}$
\end{tabular}

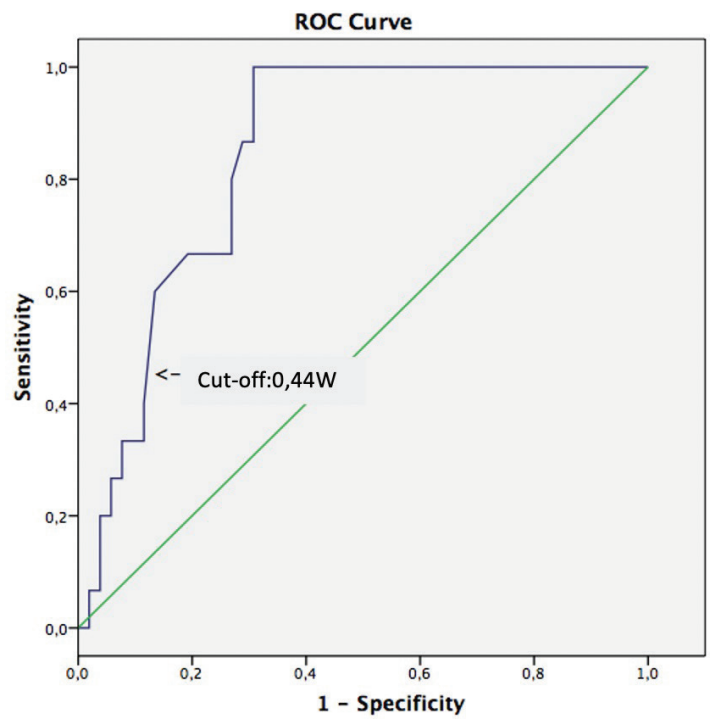

Figure-3: Area under curve and cut-off point RVCPO: right ventricular cardiac power output; ROC: Receiver operator characteristic 


\begin{tabular}{|c|c|c|c|c|}
\hline \multicolumn{5}{|c|}{$\begin{array}{c}\text { Area Under the Curve } \\
\text { Test Result Variable(s): RVCPO }\end{array}$} \\
\hline \multirow{2}{*}{ Area } & \multirow{2}{*}{ Std. Errora } & \multirow{2}{*}{$\begin{array}{l}\text { Asymptotic } \\
\text { Sig.b }\end{array}$} & \multicolumn{2}{|c|}{$\begin{array}{l}\text { Asymptotic 95\% Confi- } \\
\text { dence Interval }\end{array}$} \\
\hline & & & $\begin{array}{l}\text { Lower } \\
\text { Bound }\end{array}$ & $\begin{array}{l}\text { Upper } \\
\text { Bound }\end{array}$ \\
\hline ,846 & ,047 &, 000 & ,754 & ,937 \\
\hline \multicolumn{5}{|c|}{$\begin{array}{l}\text { The test result variable(s): RVCPO has at least one tie between the positive } \\
\text { actual state group and the negative actual state group. Statistics may be } \\
\text { biased. } \\
\text { a. Under the nonparametric assumption } \\
\text { b. Null hypothesis: true area }=0.5\end{array}$} \\
\hline
\end{tabular}

\section{DISCUSSION}

Cardiac power output represents energy per unit of time, that heart is required to pump the blood through vessels. In other words, cardiac pumping capability can be defined as the cardiac power output. It is reasonable that mortality is related to the decrease in cardiac pumping capability with advanced stages of the disease. ${ }^{8,9}$ During maximal stimulation of the heart at advanced stages, cardiac pumping capability increases from resting values to maximally forced stage owing to the reservoir $\mathrm{CPO}$ capacity. ${ }^{10}$ Over time, due to pump dysfunction, the maximal $\mathrm{CPO}$ decreases proportionally with the reservoir $\mathrm{CPO}$ consumption. ${ }^{10}$ In our study, we examined RVCPO among low, intermediate, and high-risk groups of PAH patients. RVCPO tends to increase with low and intermediate-risk groups while goes to a decline with high-risk patients due to consumption of cardiac pumping capability. Also, we demonstrated that increased RVCPO values higher than $0.44 \mathrm{~W}$ for PAH patients with low and intermediate-risk can play a role as a mortality predictor.

PAH remains a severe clinical condition despite all approved PAH therapies. Risk assessment plays a vital role in prognostication and the decision of evidence-based treatments. The current treatment strategy is based on the severity of $\mathrm{PAH}$ as assessed by a multiparametric risk stratification approach, including monotherapy, double, or triple combination therapy. As it is well known that upfront combination therapy that should include parenteral prostacyclin analogue is recommended for high-risk patients. ${ }^{11}$ But initial or sequential combination or initial monotherapy are both options in the current guidelines for low and intermediate-risk groups. Further risk stratification parameters might be necessary to discriminate who should be treated as high-risk patients considering escalation, or as low-risk patients with frequent follow-up until deterioration. Therefore Yogeswaran et al. introduced further stratification of intermediate-risk patients based on $6 \mathrm{MWD}$ and TAPSE/ systolic PAP ratio to sub-stratify patients at intermediate risk into low-intermediate and high-intermediate-risk groups. ${ }^{12}$ Starting from this point of view, we evaluated RVCPO as a new hemodynamic parameter for further risk stratification and we hypothesized that RVCPO as a predictor of mortality and as a determinant of future adverse events in patients with low and intermediate-risk groups.

We have found that RVCPO was increased to $0,41 \pm$ $0,14 \mathrm{~W}$ (Normal RVCPO is $\sim 0,21 \mathrm{~W}$ that is calculated by using reference ranges of $\mathrm{CO}$ and mPAP in the formula) for all overall study population. ${ }^{13}$ However, when we evaluated RVCPO among risk groups, it was found that RVCPO was lower in high-risk patients in comparison with low and intermediate-risk groups. This phenomenon can be explained by the RV remodeling and interdependence between right and left ventricle in response to increased $\mathrm{RV}$ afterload. In the beginning, a progressive increase in PVR results in RV pressure overload. RV initially copes with increased afterload by enhancing systolic contraction with concentric remodeling for maintenance of $\mathrm{CO}$. When the adaptive changes fail to overcome increasing afterload, the maladaptive stage initiates with dilatation of the right chambers that results in RV volume overload in addition to pressure overload. Chronic RV afterload increase induces an extensive change of cardiac morphology and function involving both ventricles. RV remodeling causes leftward displacement of the interventricular septum and induces impaired LV diastolic filling. Thus, maintenance of $\mathrm{CO}$ fails. ${ }^{14,15}$ After uncoupling of the right ventricle, the contribution of $\mathrm{CO}$ as a multiplier of RVCPO decreases. 
mPAP continues to rise proportionally with increased PVR, till the right heart fails and no longer able to generate increased pressures (Figure-2). Therefore, RVCPO is expected to be fall at the end-stage patients and the reason for the lower values at high-risk patients.

The point of view from the left heart; the subanalysis of the SHOCK trial (Should We Emergently Revascularize Occluded Coronaries for Cardiogenic Shock) by Fincke et al described LVCPO as the strongest hemodynamic correlate of outcome in cardiogenic shock, bringing this hemodynamic parameter into prominence as a measure of cardiac pumping ability. ${ }^{5}$ They have found that $0.53 \mathrm{~W}$ cut-off for LVCPO was the most accurately predict mortality. LVCPO has shown a descending course with left heart disease progression (heart failure/cardiogenic shock) while for $\mathrm{PAH}$ patients RVCPO increases to a certain extent at low and intermediate-risk than falls into a decline at advanced stages like the left heart.

Herrera et al investigated RVCPO concurrently with LVCPO previously to identify the responders of the acute vasodilatory test in the IPAH group that predicts better long-term prognosis. ${ }^{16}$ They have found that RCVPO was elevated in IPAH patients and decreased with acute vasodilatory test with responders. They have observed that a decrease in MPAP from baseline meanwhile increase in $\mathrm{CO}$ after the acute vasodilatory test. Ultimately RVCPO decreased whereas LVCPO increased, so LVCPO/RVCPO ratio was found to be raised. For the non-responder group, they mentioned that RVCPO was elevated whereas LVCPO and LVCPO/RVCPO ratio remained unchanged. We have found RCVPO was elevated at the baseline in PAH patients similarly with the mentioned study. But we have also found that RVCPO has decreased at the advanced stages. Anyhow in high-risk profiled patients, RVCPO was still above the normal ranges. We demonstrated that increased RVCPO had a significant relation with mortality (OR: 2,06, 95\% CI: 1,1-3,03, p=0,03) with low and intermediate-risk groups. RVCPO was found to be related with mor- tality especially above the $0,44 \mathrm{~W}$ cut-off value for low and intermediate risk groups.

Xie et al. evaluated RVCPO in chronic thromboembolic pulmonary hypertension $(\mathrm{CTEPH})$ patients. ${ }^{13}$ This study examined the RVCPO before and after pulmonary endarterectomy (PEA). They demonstrated that RVCPO was found to increase before PEA and decreased after PEA. The reason for the decrease in RCVPO; was explained in this study by association with RV stunning and/or disproportionate drop in mPAP after PEA. In our study, the correlation between RVCPO and its components revealed that mPAP showed a high positive correlation (correlation coefficient: $0,935, \mathrm{p}<0,001)$ while CO showed a low positive correlation (correlation coefficient: 0,465, $\mathrm{p}<0,001$ ). We suggest that remodeling as a response to increased RV afterload takes more time than observing an elevation course of MPAP as a response of pulmonary vascular remodeling. So, with the results of correlation coefficients in our study; we suggest that MPAP as a multiplier of the RVCPO might be more determinant on RVCPO than CO in PAH patients.

The ESC/ERS guidelines and Proceedings of the 2018 World Symposium on Pulmonary Hypertension recommend comprehensive risk assessment at expert PAH centers by using clinical, echocardiographic, exercise, laboratory, and hemodynamic parameters. ${ }^{7.17}$ The main takeaway received from three European studies and REVEAL study that were made to evaluate the alternative versions of this stratification in $\mathrm{PAH}$ patients is that patients who improved to a lower-risk profile at follow-up had better outcomes than those who did not improve. ${ }^{18-22}$ In the mentioned studies, it was suggested that stability should not be considered as an acceptable treatment outcome as the patients who remain "stable" in the intermediate-risk group. Because it has shown that this group of patients had poorer outcomes than low-risk profile. Determining the optimum treatment strategy in order to obtain a low-risk profile is main target of these risk assessment tools. Therefore, with 
the benefit of these tools it leads us to have an accurate discrimination of who will get more benefit from initial either dual or triple combination therapy for newly diagnosed patients. Because from the previous experiences, it is known that if patients stratified intermediate or high risk at baseline and however obtained the low-risk profile in time had similar outcomes compared to those who were initiated as low-risk profile. An initial triple combination that includes parenteral prostacyclin analogue is the most rational treatment option for high-risk patients. But discrimination of who will get more benefit from upfront dual or triple oral treatment or sequential combination with low and intermediate-risk groups becomes more of an issue. So, we suggest that RVCPO can provide additional information about mortality prediction with low and intermediate-risk at baseline.

Study limitations: The main limitations of the present study included that it was a single-center, retrospective experience. Further studies are warranted to establish to confirm our findings with an extended and follow-up study population.

\section{CONCLUSION}

Right ventricular cardiac power output could be a promising hemodynamic parameter that represents cardiac pumping ability with PAH patients. RVCPO tends to increase with low and intermediate risk while goes to a decline with high-risk patients and associated with mortality above $0,44 \mathrm{~W}$ with low and intermediate-risk patients. We suggest that RVCPO could be a beneficial hemodynamic tool to discriminate the patients at-risk among the low and intermediate-risk groups.

The ethical approval protocol code: 27.07.2020 Versiyon 1- HNEAH-KAEK 2020/KK7158 
Sakarya Med J 2021;11(4):794-802

SENA et al., : Right Ventricular Cardiac Power and Pulmonary Arterial Hypertension

\section{Kaynaklar}

1. Chatterjee K. The Swan-Ganz catheters: past, present, and future. A viewpoint. Circulation 2009; 119: 147-152.

2. Nossaman BD, Scruggs BA, Nossaman VE, Murthy SN, Kadowitz PJ. History of right heart catheterization: 100 years of experimentation and methodology development. Cardiol Rev 2010; 18: 94-101.

3. Stephan Rosenkranz, Ioana R. Preston. Right heart catheterization: best practice and pitfalIs in pulmonary hypertension. European Respiratory Review Dec 2015, 24 (138) 642-652; DOI: 10.1183/16000617.0062-2015

4. Cotter G., Williams SG, Vered Z., Tan LB. Role of cardiac power in heart failure. Curr Opin Cardiol. 2003;18:215-22.

5. Rupert Fincke, Judith S. Hochman, April M. Lowe, Menon V, Slater JN, Webb JG, et al. Cardiac power is the strongest hemodynamic correlate of mortality in cardiogenic shock: A report from the SHOCK trial registry. J Am Coll Cardiol 2004; 44:340-8.

6. Williams SG, Cooke GA, Wright DJ, Parsons WJ, Riley RL, Marshall P, et al. Peak exercise cardiac power output; a direct indicator of cardiac function strongly predictive of prognosis in chronic heart failure. Eur Heart J.2001;22:1496-503.

7. Galiè N, Humbert M, Vachiery JL, Gibbs S, Lang I, Torbicki A, et al. 2015 ESC/ERS Guidelines for the diagnosis and treatment of pulmonary hypertension: The Joint Task Force for the Diagnosis and Treatment of Pulmonary Hypertension of the European Society of Cardiology (ESC) and the European Respiratory Society (ERS): Endorsed by: Association for European Paediatric and Congenital Cardiology (AEPC), International Society for Heart and Lung Transplantation (ISHLT). Eur Heart J. 2016;37(1):67-119. doi:10.1093/eurheartj/ehv317

8. Champion HC, Michelakis ED, Hassoun PM. Comprehensive invasive and noninvasive approach to the right ventricle-pulmonary circulation unit: state of the art and clinical and research implications. Circulation. 2009;120(11):992-1007. doi:10.1161/CIRCULATIONAHA.106.674028

9. Lupi HE, Chuquiure VE, González PH, González Pacheco H, Cuéllar Velasco BM, Arias Mendoza A, et al. "Cardiac Power Output" an old tool, possibly a modern tool for assessing cardiac pumping capability, as well as for a short-term prognosis in cardiogenic shock due to acute myocardial infarction. Arch Cardiol Mex. 2006;76(1):95-108.

10. Yildiz, O., Aslan, G., Demirozu, Z. T., Yenigun, C. D., Yazicioglu, N. (2017). Evaluation of Resting Cardiac Power Output as a Prognostic Factor in Patients with Advanced Heart Failure. The American Journal of Cardiology, 120(6), 973-979.doi:10.1016/j.amjcard.2017.06.028

11. Hoeper, MM Kramer, T, Pan, Z, Eichstaedt CA, Spiesshoefer J, Benjamin N, et al. Mortality in pulmonary arterial hypertension prediction by the 2015 European pulmonary hypertension guidelines risk stratification model. Eur Respir J 2017; 50: 1700740.
12. Yogeswaran A, Richter MJ, Sommer N, Ghofrani HA, Seeger W, Tello K, et al. Advanced risk stratification of intermediate risk group in pulmonary arterial hypertension. Pulmonary Circulation. October 2020. doi:10.1177/2045894020961739

13. Yu Xie, William Auger, Michael Madani. Right ventricular cardiac power output is inversely related to pulmonary vascular resistance in chronic thromboembolic pulmonary hypertension. J Am Coll Cardiol. 2012 Mar, 59 (13 Supplement) E1610.

14. Nazzareno Galié, Alessandra Manes, Massimiliano Palazzini, Negro L., Romanazzi S., Branzi A. Pharmacological impact on right ventricular remodelling in pulmonary arterial hypertension, European Heart Journal Supplements, Volume 9, Issue suppl_H, 1 December 2007, Pages H68-H74, https://doi.org/10.1093/eurheartj/sum055

15. A. Vonk Noordegraaf, N. Galie. The role of the right ventricle in pulmonary arterial hypertension. European Respiratory Review Dec 2011, 20 (122) 243-253; DOI: $10.1183 / 09059180.00006511$

16. Lupi-Herrera E, Sandoval J, Figueroa J, Carrillo A, Aguirre R, Santos-Martínez LE, et al. Left and right ventricular power: outputs are the strongest hemodynamic correlates to allow identification of acute responders to vasodilator treatment in idiopathic pulmonary arterial hypertension. Arch Cardiol Mex. 2011 Apr-Jun;81(2):100-7. PMID: 21775243.

17. Condon DF, Nickel NP, Anderson R, Mirza S, de Jesus Perez VA. The 6th World Symposium on Pulmonary Hypertension: what's old is new. F1000Res. 2019 Jun 19;8:F1000 Faculty Rev-888. doi: 10.12688/f1000research.18811.1. PMID: 31249672; PMCID: PMC6584967.

18. Hoeper MM, Kramer T, Pan Z, Eichstaedt CA, Spiesshoefer J, Benjamin N, et al. Mortality in pulmonary arterial hypertension: prediction by the 2015 European pulmonary hypertension guidelines risk stratification model. Eur Respir J 2017; 50: 1700740.

19. Boucly A, Weatherald J, Savale L, Jaï X, Cottin V, Prevot G, et al. Risk assessment, prognosis and guideline implementation in pulmonary arterial hypertension. Eur Respir J 2017; 50: 1700889.

20. Gall, H, Felix, JF, Schneck, FK, Milger K, Sommer N, Voswinckel R, et al. The Giessen Pulmonary Hypertension Registry: survival in pulmonary hypertension subgroups. J Heart Lung Transplant 2017; 36: 957-967.

21. Benza RL, Gomberg-Maitland M, Miller DP, Frost A, Frantz RP, Foreman AJ, et al. The REVEAL Registry risk score calculator in patients newly diagnosed with pulmonary arterial hypertension. Chest 2012;141:354-62.

22. Benza RL, Elliott CG, Farber HW, et al. Updated Risk Score Calculator for Patients with Pulmonary Arterial Hypertension (PAH) in the Registry to Evaluate Early and Long-Term PAH Disease Management (REVEAL). Am J Respir Crit Care Med 2017;195:A6899-A. 